\title{
Evaluating the Contribution of E-Government Services Achieving Sustainable Development Goals (SDGs) A Case Study of Egypt
}

\author{
Ibrahem Mohamed Mohamed Ramadan PhD. \\ Faculty of Commerce \& Business Administration \\ Helwan University, Egypt \\ Cairo, Egypt
}

\begin{abstract}
Due to limited researches in Egypt linking between E-government with Sustainable Development Goals. This study aims to clarify contribution of Egovernment services in achieving SDGs and some of its literary references and the relationship between them by using a methodology clarifying the relationship between the SDGs and the e-government services and provides the researchers and anyone wants to improve or add a new service to E-government services or achieve the SDGs and its domains with data that help them ease of choice and decision making.
\end{abstract}

E-government services have been sorted and tested to verify whether these services are available or not. furthermore, classification of SDGs and linking eservices to them has been provided through a matrix assessing Egyptian E-government services parameters to achieve SDGs and targets.

This study has found that almost all Egypt Ministries and other governmental organizations have websites, mostly used for providing structural information functions, activities, news, and services helping in achieving SDGs. Despite the limited number of Egyptian e-services and their domains, it contributes to the achievement of 11 goals (about 65\%) and 33 SDG targets (about $20 \%$ ).

Keywords:- SDGs; E-government; UN; Egypt; Egovernment Services; Sustainable Development Goals.

\section{INTRODUCTION}

On September 2015, at an historic UN Summit and in the presence of 193 countries. The 2030 agenda for Sustainable Development Goals (SDGs) was adopted, it included 17 SDGs. The SDGs comprise a new broad range of economic, social and environmental goals that universally apply to all, the governments have been working on achieving Sustainable Development Goals (SDGs).

E-government has developed across the world over last year's rapidly, the focus of E-government evaluation is moving from merely technical issues to issues that span the social, political, cultural and economic environment.

\author{
Ass.Prof. Dr Manal Abd Alkader Abd Alfatah \\ Faculty of Computers and Information \\ Helwan University, Egypt \\ Cairo, Egypt
}

E-Government provides to Sustainable Development the transparency through open data, greater efficiency, effectiveness, better access, quality of services, economic growth, social Inclusion,

Environmental protection and enhanced citizen participation. And many of the SDGs have goals directly or indirectly related to the indicators of local e-government evaluation which makes the improvements in the evaluation of e-government work as a catalyst for achieving the goals of sustainable development.

So, Governments around the world are becoming increasingly aware of the importance of using Egovernment to improve delivery of public services to citizens besides the importance of SDGs achievement prior to 2030 .

Egypt, a country of high ambitions regarding information and communications technology, Egovernment and SDG's achievement. furthermore, Currently Egyptian governmental websites became more developed and multilingual (Arabic and English) but most of the websites are designed for Arabic because most Egyptians speak only Arabic thus, citizens can use most State websites and most of these websites are updated.

\section{RESEARCH BACKGROUND}

\section{$>$ E-Government: -}

The researchers' studied the adoption, use and domestication of technology in society focusing on societal consequences of technology domestication. (1) So , Egovernment has developed across the world over last year's rapidly. (2) The focus of E-government evaluation is moving from merely technical issues to issues that span the social, political, cultural and economic environment. (3)

Electronic government or E-government is the use of information technology to enable and improve efficiency through which governmental services are provided to citizens, employees, businesses and agencies. (4) Delivering multiple services for a wide range of users such as employees (G2E), citizens (G2C), business (G2B) and to other government departments (G2G). (5) While each user has their specific concern and claim to adopt E-government services. (6) 
E-government benefits improving quality of citizen delivered services, as enhances better public sectorefficiencies and Law enforcement, it reduces corruption and increases transparency, as enables better information dissemination. It enhances promotion of governmental services and outreach, as facilitates more involvement of citizens in democratic processes. (7) It provides greater convenience, as empowers citizens through access to information, growth of revenues, cost reductions, and increase efficient government management among others. (8)Purpose is: 1- improving government services and Webbased service delivery; 2- linking between governmental agencies; 3- Citizen access to government information 4Procurement, and payment; 5- Citizen participation . (9)
The Sustainable Development Goals (SDGs):

On September 2015, at an historic UN Summit and in the presence of 193 countries. The 2030 agenda SDGs was adopted, it included 17 SDGs (as shown in Fig 1 ) and 169 targets. (See - Table 4 - Appendix) (10) .

The SDGs comprise a new broad range of economic, social and environmental( as shown in Fig 2:Classification by domains- below ) objectives that universally apply to all, and over the next fifteen years countries will mobilize efforts to end all forms of poverty, fight inequalities and tackle climate change while ensuring that no one is left behind.
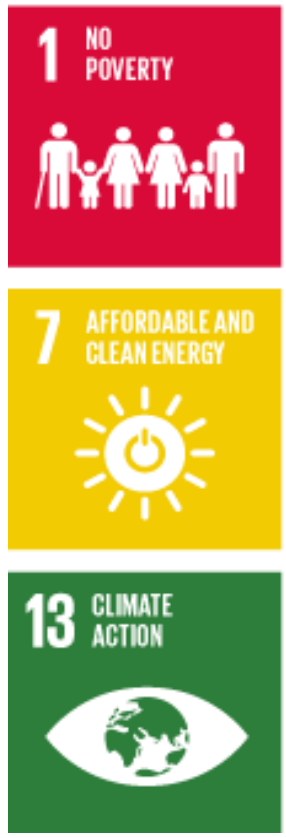
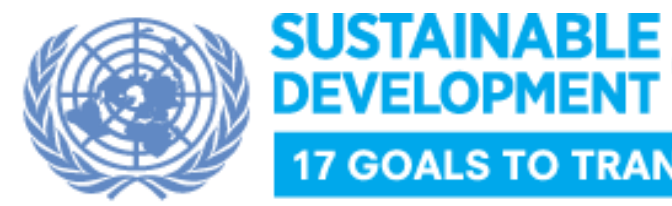

17 GOALS TO TRANSFORM OUR WORLD
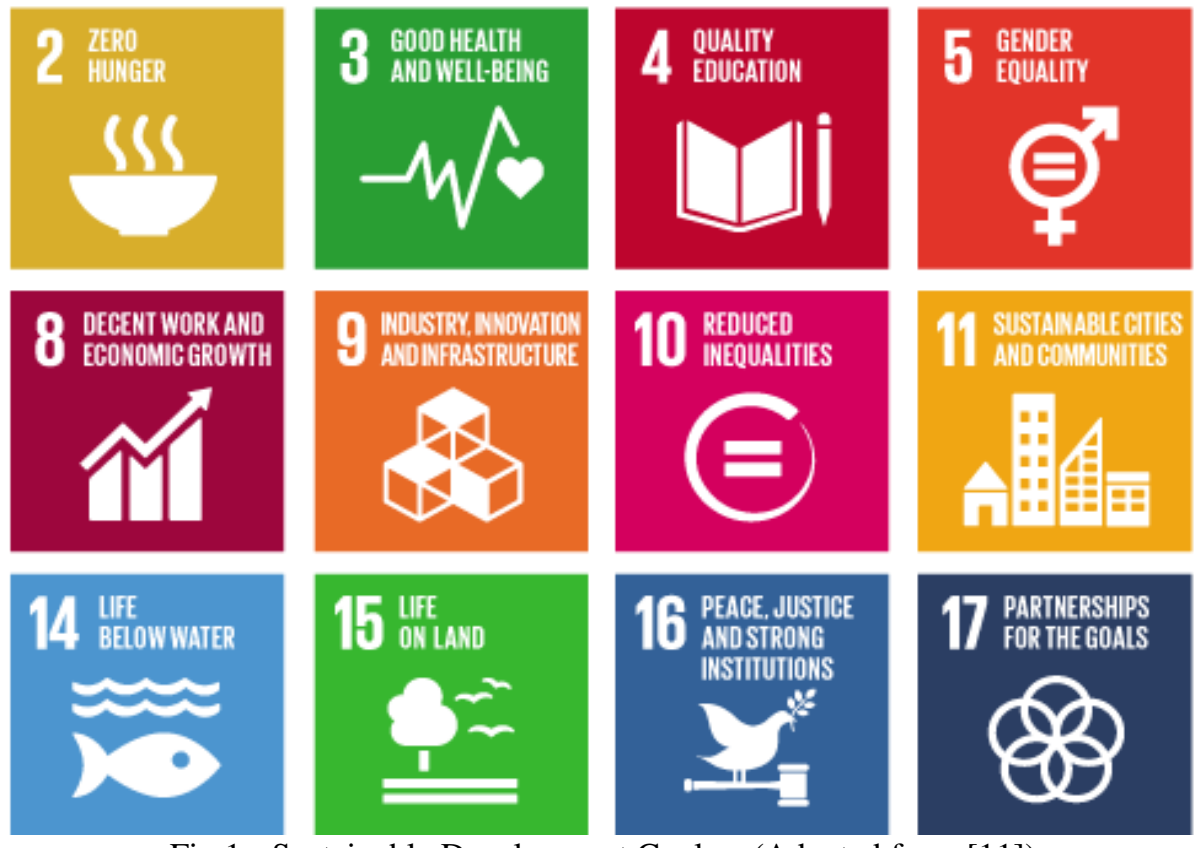

rom [11])
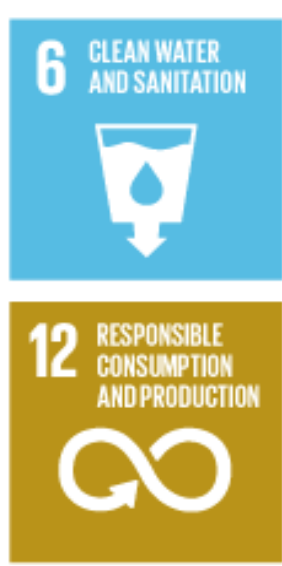

SUSTAINABLE DEVELOPMENT G.1. 


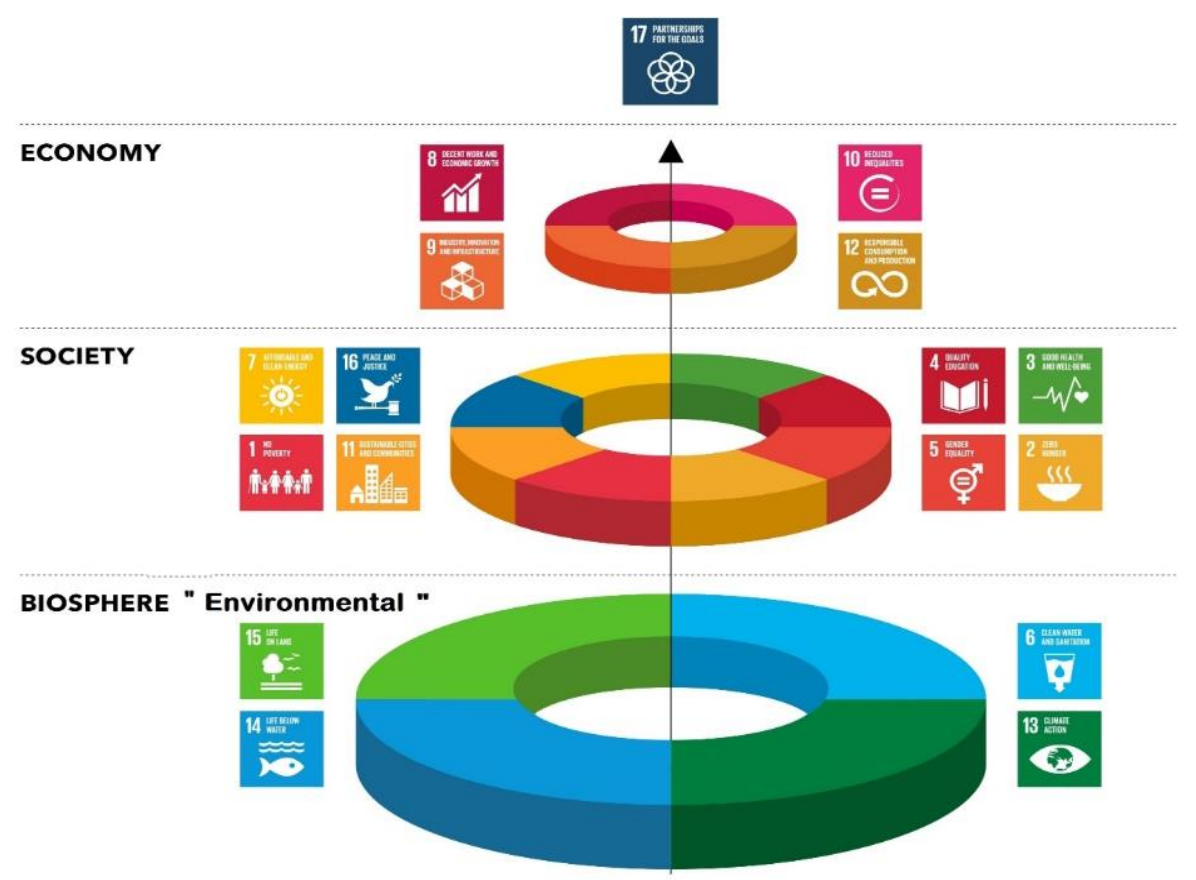

Fig 2:- Classification by domains

Source: Stockholm Resilience Center - Stockholm University

\section{E-Government for Sustainable Development}

E-Government provides to Sustainable Development the transparency through open data, greater efficiency, effectiveness, better access, quality of services, economic growth, social Inclusion, environmental protection, and enhanced citizen participation. (12)

Many of the SDGs in the agenda 2030 have goals directly or indirectly related to the indicators of local egovernment evaluation, which makes the improvements in the evaluation of e-government work as a catalyst for achieving the goals of sustainable development.

So, online service provision leads to empowering and promoting social, economic, Environmental and political inclusion on the elimination of discriminatory laws and practices, ensuring equal opportunities and reducing inequality in outcomes and practices and strengthening appropriate legislation and procedures and e-participation, including e-consulting (As shown by the UN e-government survey for 2018). (13)

\section{E-Government in Egypt:}

The Egyptian government is making great efforts to develop an appropriate framework for E-government. Important steps have been taken developing the national Egovernment infrastructure.

The E-government portal - www.Egypt.gov.eg - was launched in 2004, containing government information and Ministries websites as well as other governmental organizations.

Egypt won the United Nations public service awards (UNPSA) ( as depicted in Table 1) . (14) (15) (16) (17)

\begin{tabular}{|c|c|c|c|}
\hline Year & Category & Place Winner & Initiative \\
\hline 2003 & 2 & 3 & $\begin{array}{c}\text { The Ministry of State for Administrative Development Providing faster service } \\
\text { to citizens by Automating Service Request procedures }\end{array}$ \\
\hline 2009 & 2 & 5 & "e-Tanseek - University Enrollment Project" \\
\hline 2011 & 1 & 2 & Government Procurement Portal \\
\hline 2011 & 5 & 1 & Eomen Health Outreach Program \\
\hline 2012 & 2 & 2 & Information Center - Ministry of Communication and Information Technology \\
\hline 2013 & 2 & 1 & Multidisciplinary Breast Cancer Clinic - Women Health Outreach Program \\
\hline 2013 & 5 & 1 &
\end{tabular}

Table 1:- Egypt won the United Nations Public Service Awards 
The UN global E-government survey represents a comparative world-country ranking according to two primary indicators: (18) (19) (13) The first is E-government Development Index (EGDI) which is a weighted average of three normalized scores on three most important dimensions of E-government, namely: Online Service Index (OSI), Telecommunication Infrastructure Index (TII) and the Human Capital Index (HCI), and the second is E-participation Index.

Egypt's rank according to UN E-government survey conducted in 2014, 2016 and 2018. ( as depicted in Table 2).

\begin{tabular}{|c|c|c|c|c|c|c|c|}
\hline Year & Rank & EGDI & OSI & TII & HCI & EPI & Trend \\
\hline 2014 & $80 / 193$ & 0.513 & 0.591 & 0.357 & 0.591 & 0.549 & -27 \\
\hline 2016 & $108 / 193$ & 0.459 & 0.471 & 0.303 & 0.605 & 0.406 & +28 \\
\hline 2018 & $114 / 193$ & 0.488 & 0.534 & 0.322 & 0.607 & 0.539 & +6 \\
\hline
\end{tabular}

Table 2:- Rank of Egypt in UN E-Government Survey

Currently Egyptian governmental websites became more developed and multilingual (Arabic and English) but most of the websites are designed for Arabic because most Egyptians speak only Arabic thus, citizens can use most State websites and most of these websites are updated.

\section{RESEARCH LIMITATION}

As the scope of this research is E-government services and sustainable development goals in Egypt. So the limits of research have been identified (as depicted in Table 3 - below ).

\begin{tabular}{|c|c|c|}
\hline Element & E-government services & \multicolumn{1}{c|}{ EDGs } \\
\hline Country & \multicolumn{1}{|c|}{ Between Jun $7^{\text {th }}, 2018$ and Dec 31 $1^{\text {st, } 2019 .}$} \\
\hline Time of Sorting and Testing & $\begin{array}{c}\text { Egypt E-government Portal, } \\
\text { Governorates Websites, Ministries } \\
\text { Websites and Governmental } \\
\text { Organizations }\end{array}$ & \\
\hline Classification & $\begin{array}{c}\text { Service providers Classification } \\
\text { UN Classification }\end{array}$ \\
\hline
\end{tabular}

Table 3:- Research Limitation

\section{RESEARCH METHODOLOGY}

As the scope of this research is E-government services and SDGs in Egypt. Therefore, e-services in Egypt will be displayed, sorted and tested, then classified according to SDGs, Then E-services will be linked to SDGs to derive an assessment matrix Egyptian E-government Service Parameters towards achieving SDGs and targets (as shown in ).

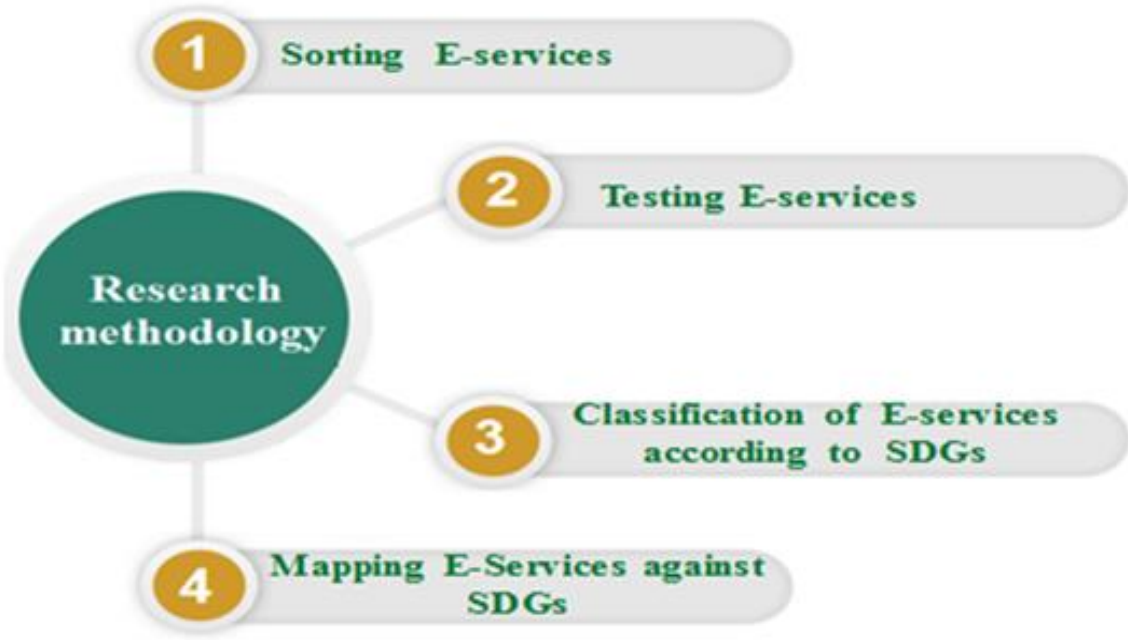

Fig 3:- Research Methodology 


\section{Sorting E-services Stage}

Egypt has more governmental web pages on the world wide web, the sorting of E-government services was done according to the research limits( see Table 3 - above), which identified 67 Government Websites. 34 for Ministries, 25 for Governorates and 8 for Governmental Organizations other than the Egypt E-government Portal. (See - Table 5 - Appendix)

\section{Testing Stage}

The main testing approach that used in this study is verifying whether Governmental websites services are available or not. and the process of testing has been revealed that 16 service providers are available and 19 forms "Template" which can be printed and submitted directly on service request. (See - Table 5:- List of Egyptian Ministries, Governorates and other Egyptian Governmental Organizations

and Table 6:- List of Egyptian E-Government Services

$$
\text { - Appendix) }
$$

\section{Classification of e-services according to SDGs Stage}

During the test stage and according to the research limits, there were 16 service providers, out of which 8 only match SDG domains, However, during this stage, the Eservices were classified according to SDGs covering domains of (Health, Social Protection, Economic Growth, Employment \& Decent Work, Environmental Protection,
Public Security and , Education) (21) ( See - Error! Reference source not found. - Appendix )

$>$ Mapping E-Services against SDGs

During the classification phase there were only 8 service providers that match different SDG domains. At this stage e-services and SDGs were classified according to domains to obtain assessment parameters matrix used in Egyptian E-government Services to achieve SDGs and targets. (See - Table 9 and Table 10 -Appendix)

\section{Discussion}

As the scope of this research is E-government services and SDGs in Egypt. So, e-services will be displayed, sorted according to the research limits, which identified 67 Government Websites. 34 for Ministries, 25 for Governorates and 8 for Governmental Organizations other than the E-Government Portal Verifying whether services are available or not. The process of testing reveal that 16 service providers are available with 19 forms "Template" which can be printed and submitted directly on service request., During this stage E-services were classified according to SDGs covering domains of: Health, Social Protection, Economic Growth, Employment \& Decent Work, Environmental Protection, Public Security and Education. E-services were then corresponded to SDGs to obtain the Egyptian E-government service parameters assessment matrix towards achieving SDGs and targets.

The study concluded 16 service providers in the Egovernment, only 8 services providers match SDG domains, and despite the low number of Egyptian eservices and their domains, it contributes towards the achievement of 11 goals (about 65\%) (See Figure 5) and 33 SDG Targets (about $20 \%$ ) (See Figure 4 ).

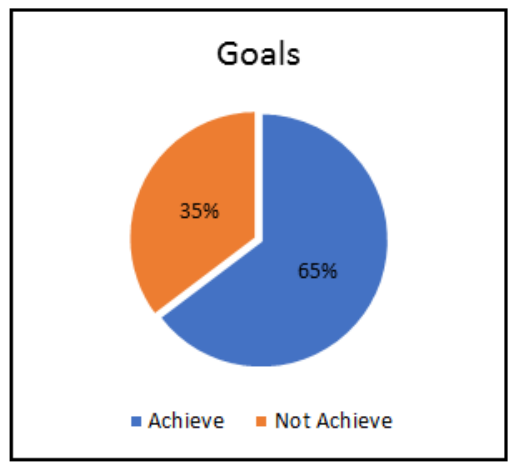

Fig 3:- SDGs

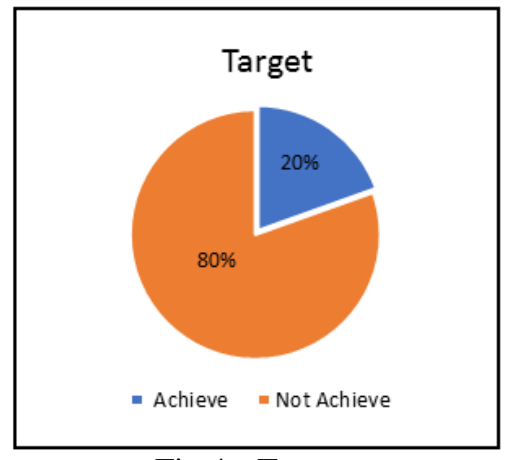

Fig 4:- Targets 


\section{CONCLUSIONS AND RECOMMENDATIONS FOR FUTURE WORK}

This study has found that almost all Egypt Ministries and other governmental organizations have websites, mostly used for providing structural information functions, activities, news, and services helping in achieving SDGs, and also Our study provides to the researchers and anyone wants to improve, add a new service to E-government services or achieve the SDGs and its domains with data that help them ease of choice and decision making.

These data include:

Tables which contain the list of E-government services available in Egypt, and List of Egyptian Ministries, Governorates, and other Egyptian Governmental Organizations.

$>$ Clarification mapping which Classifies E-government Services According to SDGs Domains.

$>$ Assessment parameters matrix used in Egyptian Egovernment Services to achieve SDGs and targets.

At the end of the study and upon sorting and testing eservices, it was found that there are 16 E-government service providers. Upon classification of SDGs only 8 services providers match SDG domains, and despite the low number of Egyptian e-services and their domains, it contributes towards the achievement of 11 goals (about $65 \%$ ) and 33 SDG targets (about $20 \%$ ).

For future work, an enhancing E-Government services will be proposed to achieve SDGs and to make available many e-services that contribute to such.

\section{REFERENCES}

[1]. Life in the real - mobile telephones and urban metabolism. Townsend, A.M. Journal of Urban Technology, Vols. no. 7, 200, pp. 85-104.

[2]. Public Transactional e-Services through Government Web Sites in Kyrgyzstan. Ulan Brimkulov and Kasym Baryktabasov. 1, 2014, Electronic Journal of e-Government, Vol. 12, pp. 1-15.

[3]. Why the interpretive paradigm is needed for evaluating e-government systems? Dr.Manal AbdelKader Abdel-Fattah, Dr.Galal Hassan GalalEdeen. 2009, researchgate, Vol. Interpretive_Paradigm_V7, pp. 2-12.

[4]. The utilization of e-government services citizen trust, innovation and acceptance factors. Lemuria Carter \& France Bélanger. 15, 2005, Info Systems, pp. 121.

[5]. Study of Some E-Government Activities in South Africa. Surendra Thakur, Shawren Singh. June 2013, African Journal of Computing \& ICT, Vol. 6. No. 2, p. 1.

[6]. Factors Influencing Adoption and Diffusion of eGovernment Services. Dr .Manal Abdel Kader Abdel Fattah. 2014, researchgate, pp. 2-11.
[7]. Citical success factors and key performance indicators for e-government projects: The case of Mauritius. Govinda, S. P. \& Chittoo, H. B. Cairo, Egypt : s.n., 5th - 6th June 2008. Log-in Africa e-local governance international conference.

[8]. A Consumer Based Model for Adoption of E-Tax Services in Uganda. Asianzu E. \& Maiga G. [ed.] Paul Cunningham and Miriam Cunningham (Eds) Proceedings. s.l. : International Information Management Corporation - " IIMC ", 2012. ISTAfrica Conference . Vols. ISBN: 978-1-905824-34-2.

[9]. Realizing the Promise of Digital Government: It's More than Building a Web Site. Pardo. October-2000, Information Impact.

[10]. United Nations. Transforming our world: the 2030 agenda for sustainable development. sustainabledevelopment goals. [Online] 2015 . [Cited: 1 19, 2019.] https://sustainabledevelopment.un.org/post2015/transf ormingourworld.

[11]. University, Stockholm. How Stockholm Resilience Centre (SRC) - contributed to the 2016 Swedish Agenda 2030 High-Level Policy Forum report. Stockholm Resilience Centre. Swedish : on Stockholm University web side.

[12]. United Nations Project Office on Governance (UNPOG). E-Government for Sustainable. s.l. : Mr. Jae-hong Lim (Head of UNPOG). p. (10/37).

[13]. UNITED NATIONS. UNITED NATIONS EGOVERNMENT SURVEY. 2018.

[14]. Nations, United. Good Practices and Innovations in Public Governance. United Nations Public Service Awards. 2003-2011.

[15]. Awards, United Nations Public Service. Good Practices and Innovations in Public Governance. 2012-2013.

[16]. Ministry of Communications and Information Technology. [Online] [Cited: 1 6, 2019.] http://www.mcit.gov.eg/Media_Center/Press_Room/P ress_Releases/2689.

[17]. Knowledge Base of UN Public Service Awards Initiatives. [Online] [Cited: 1 25, 2019.] https://publicadministration.un.org/en/Research/CaseStudies/unpsacases/ctl/NominationSearch/mid/1170.

[18]. UNITED NATIONS. UNITED NATIONS EGOVERNMENT SURVEY. 2014.

[19]. UNITED NATIONS,. UNITED NATIONS EGOVERNMENT SURVEY. 2016.

[20]. United Nations. E-Government Knowledgebase. UN - E-Government Knowledgebase. [Online] Department of Economic and Social Affairs - United Nations. [Cited: $\quad 1 \quad 18, \quad 2019$. https://publicadministration.un.org/egovkb/en-us/.

[21]. Benchmark Global e-Government Development. un public Administration programme - Department of Economic and Social Affairs. 2018. Gearing egovernment to support transformation towards sustainable and resilient societies. 


\section{APPENDIX}

\begin{tabular}{|c|c|c|c|c|}
\hline Goals number & Description & main Target & Sub-Target & Total of Target \\
\hline 1 & No poverty & 5 & 2 & 7 \\
\hline 2 & Zero hunger & 5 & 3 & 8 \\
\hline 3 & Good healthy and well-being & 9 & 4 & 13 \\
\hline 4 & Quality education & 7 & 3 & 10 \\
\hline 5 & Gender equality & 6 & 3 & 9 \\
\hline 6 & Clean water and sanitation & 6 & 2 & 8 \\
\hline 7 & Affordable and Clean & 3 & 2 & 5 \\
\hline 8 & Decent work and economic growth & 10 & 2 & 12 \\
\hline 9 & Industry innovation and infrastructure & 5 & 3 & 8 \\
\hline 10 & Reduced inequalities & 7 & 3 & 10 \\
\hline 11 & Sustainable cities and communities & 7 & 3 & 10 \\
\hline 12 & Responsible consumption and production & 8 & 3 & 11 \\
\hline 13 & climate action & 3 & 2 & 5 \\
\hline 14 & Life below water & 7 & 3 & 10 \\
\hline 15 & Life on land. & 9 & 3 & 12 \\
\hline 16 & Peace justice and strong institutions & 10 & 2 & 12 \\
\hline 17 & Partnerships for the goals & 19 & 0 & 19 \\
\hline 17 & Total & 126 & 43 & 169 \\
\hline
\end{tabular}

Table 4:- Total of Goals and Target in Sustainable Development Goals.

\begin{tabular}{|c|c|c|}
\hline S.N. & Web Site Title & URL \\
\hline 1 & The Cabinet of Ministers & http://www.cabinet.gov.eg \\
\hline 2 & Ministry of Defense and Military Production & http://www.mod.gov.eg \\
\hline 3 & Ministry of State for Military Production & http://www.momp.gov.eg \\
\hline 4 & Ministry of Petroleum and Mineral Wealth & http://www.petroleum.gov.eg \\
\hline 5 & Ministry of Electricity and Renewable Energy & http://www.moee.gov.eg \\
\hline 6 & Ministry of Foreign Affairs & http://www.mfa.gov.eg \\
\hline 7 & Ministry of Environment & http://www.eeaa.gov.eg \\
\hline 8 & $\begin{array}{c}\text { Ministry of Communication and Information } \\
\text { Technology }\end{array}$ & http://www.mcit.gov.eg \\
\hline 9 & Ministry of Education and Technical Education & http://www.moe.gov.eg/ \\
\hline 10 & Ministry of Manpower & http://www.manpower.gov.eg \\
\hline 11 & Ministry of Justice & http://www.jp.gov.eg/ar/Default.aspx \\
\hline 12 & Ministry of Local Development & http://www.mold.gov.eg \\
\hline 13 & $\begin{array}{l}\text { Ministry of Housing Utilities and Urban } \\
\text { Communities }\end{array}$ & http://www.moh.gov.eg \\
\hline 14 & Ministry of Religious Endowment & http://www.awkaf.org \\
\hline 15 & Ministry of Interior Affairs & http://www.moiegypt.gov.eg \\
\hline 16 & Ministry of Commerce and Industry & http://www.mfti.gov.eg \\
\hline 17 & Ministry of Finance & http://www.mof.gov.eg \\
\hline 18 & Ministry of Civil Aviation & http://www.civilaviation.gov.eg \\
\hline 19 & Ministry of Transportation & http://www.mot.gov.eg \\
\hline 20 & Ministry of Culture & http://www.moc.gov.eg/ \\
\hline
\end{tabular}


ISSN No:-2456-2165

\begin{tabular}{|c|c|c|}
\hline S.N. & Web Site Title & URL \\
\hline 21 & Ministry of Health and Population & http://www.mohp.gov.eg \\
\hline 22 & Ministry of Water Resources and irrigation & http://www.mwri.gov.eg \\
\hline 23 & Ministry of Agriculture and Land Reclamation & http://www.agr-egypt.gov.eg \\
\hline 24 & $\begin{array}{c}\text { Ministry of Investment and International } \\
\text { Cooperation }\end{array}$ & http://www.gafi.gov.eg/arabic/Pages/default.aspx \\
\hline 25 & Ministry of Tourism & http://www.egypt.travel \\
\hline 26 & $\begin{array}{l}\text { Ministry of Planning Monitoring and } \\
\text { Administrative Reform }\end{array}$ & http://www.mpmar.gov.eg \\
\hline 27 & $\begin{array}{c}\text { Ministry of Higher Education and Scientific } \\
\text { Research }\end{array}$ & http://portal.mohesr.gov.eg/ar-eg/Pages/default.aspx \\
\hline 28 & Ministry of Supply and Internal Trading & http://www.msit.gov.eg \\
\hline 29 & Ministry of Antiquities and Heritage & http://www.antiquities.gov.eg \\
\hline 30 & Ministry of Youth and Sports & http://www.emss.gov.eg \\
\hline 31 & Minister for Parliamentary Affairs & Www.parliament.gov.eg \\
\hline 32 & Ministry of Social Solidarity & http://www.moss.gov.eg \\
\hline 33 & $\begin{array}{c}\text { Ministry of Immigration and Egyptian } \\
\text { Expatriates Affairs }\end{array}$ & http://www.emigration.gov.eg \\
\hline 34 & Ministry of Business Sector & www.bsic.gov.eg \\
\hline 35 & Ismailia Governorate & http://www.ismailia.gov.eg/ \\
\hline 36 & Monofiya Governorate & http://www.monofeya.gov.eg/Default.aspx \\
\hline 37 & Cairo Governorate & http://www.cairo.gov.eg/Default.htm \\
\hline 38 & Fayoum Governorate & http://www.fayoum.gov.eg/default.aspx \\
\hline 39 & Giza Governorate & http://www.giza.gov.eg/Default.aspx \\
\hline 40 & Qaliobia Governorate & http://www.qaliobia.gov.eg/ \\
\hline 41 & Suez Governorate & http://www.suez.gov.eg/ \\
\hline 42 & Domyat Governorate & http://www.domyat.gov.eg/ \\
\hline 43 & Matrouh Governorate & http://matrouh.gov.eg/tadaman.aspx \\
\hline 44 & Newvalley Governorate & http://www.newvalley.gov.eg/ \\
\hline 45 & Luxor Governorate & http://www.luxor.gov.eg/default.aspx \\
\hline 46 & Minia Governorate & http://www.minia.gov.eg/default.aspx \\
\hline 47 & sharkia Governorate & http://www.sharkia.gov.eg/default.aspx \\
\hline 48 & Kafr el sheikh Governorate & www.kafrelsheikh.gov.eg/ \\
\hline 49 & Beni sueif Governorate & http://www.benisuef.gov.eg \\
\hline 50 & Alex Governorate & http://www.alexandria.gov.eg \\
\hline 51 & Aswan Governorate & http://www.aswan.gov.eg \\
\hline 52 & Assiut Governorate & http://assiut.gov.eg/ \\
\hline 53 & Redsea Governorate & http://www.redsea.gov.eg/IntoPage.aspx \\
\hline 54 & Portsaid Governorate & http://www.portsaid.gov.eg \\
\hline 55 & Southsina Governorate & http://www.southsinai.gov.eg \\
\hline 56 & Dakahliya Governorate & http://www.dakahliya.gov.eg/ \\
\hline 57 & Sohag Governorate & http://www.sohag.gov.eg/ \\
\hline 58 & North Sinai Governorate & http://www.northsinai.gov.eg \\
\hline 59 & Qena Governorate & http://www.qena.gov.eg \\
\hline 60 & EGYPT POST & https://www.egyptpost.org/lost.aspx \\
\hline 61 & Government complaints & http://www.shakwa.eg/GCP/Default.aspx \\
\hline 62 & Government Procurement & https://www.etenders.gov.eg/ \\
\hline 63 & Public service map & https://www.etenders.gov.eg/ \\
\hline 64 & Industrial Development Authority & http://www.ida.gov.eg \\
\hline 65 & National elections authority & www.elections.eg/ \\
\hline 66 & Egypt's information portal & http://www.eip.gov.eg/Services/ServiceList.aspx \\
\hline 67 & Egyptian constitution & http://sharek.dostour.eg/ \\
\hline
\end{tabular}

Table 5:- List of Egyptian Ministries, Governorates and other Egyptian Governmental Organizations 
ISSN No:-2456-2165

\begin{tabular}{|c|c|c|c|}
\hline S.N. & Service Provider & Service & URL \\
\hline \multirow{2}{*}{1} & \multirow{2}{*}{$\begin{array}{l}\text { Ministry of Health and } \\
\text { Population }\end{array}$} & $\begin{array}{l}\text { A distribution system for doctors } \\
\text { in hospitals and medical centres }\end{array}$ & http://mhealth.cu.edu.eg \\
\hline & & $\begin{array}{l}\text { Alexandria Dental Research } \\
\text { Center }\end{array}$ & http://www.adrcegypt.com \\
\hline \multirow{3}{*}{2} & \multirow[t]{2}{*}{ Ministry of Justice } & \multirow{2}{*}{$\begin{array}{l}\text { Ministry of Justice and } \\
\text { The interests of the real estate } \\
\text { and Documentation }\end{array}$} & $\frac{\text { http://www.egypt.gov.eg/services/listServicesCategory }}{\underline{\text { aspx?ID=1301\&section=serviceproviders }}}$ \\
\hline & & & http://rern.gov.eg \\
\hline & Ministry of Interior & Civil Status Organization & $\underline{\text { https://cso.moi.gov.eg }}$ \\
\hline 3 & Ministry of Environment & $\begin{array}{c}\text { Services of the Ministry of } \\
\text { Environment }\end{array}$ & http://www.eeaa.gov.eg/en-us/services.aspx \\
\hline \multirow[t]{2}{*}{4} & \multirow[t]{2}{*}{$\begin{array}{l}\text { Electricity Holding } \\
\text { Company Egypt }\end{array}$} & \multirow[t]{2}{*}{$\begin{array}{l}\text { Electricity Regulatory Authority } \\
\text { And consumer protection }\end{array}$} & $\frac{\text { http://www.egypt.gov.eg/services/listServicesCategory }}{\text {.aspx?ID=1308\&section=serviceproviders }}$ \\
\hline & & & http://egyptera.org/ar/a7sb\%20fatortk.aspx \\
\hline 5 & $\begin{array}{l}\text { Egyptian } \\
\text { Telecommunication } \\
\text { Company }\end{array}$ & $\begin{array}{l}\text { Egyptian Telecommunication } \\
\text { Company }\end{array}$ & https://billing.te.eg/ar-EG/Login\#PayMyBills \\
\hline 6 & Egypt Railways Authority & Egypt Railways & https://enr.gov.eg/ticketing/public/login.jsf \\
\hline 7 & Egypt Air & Egypt Air & https://www.egyptair.com/ar/Pages/HomePage.aspx \\
\hline 8 & $\begin{array}{l}\text { General Organization for } \\
\text { Standardization } \\
\text { Standard and quality } \\
\end{array}$ & $\begin{array}{l}\text { General Organization for } \\
\text { Standardization } \\
\text { Standard and quality } \\
\end{array}$ & http://www.eos.org.eg/ar \\
\hline 9 & Ministry of Investment & Investment Authority Services & $\frac{\text { http://www.gafi.gov.eg/Arabic/eServices/Pages/default }}{\underline{\text { aspx }}}$ \\
\hline 10 & Customs Department & Services customs & /http://www.customs.gov.eg \\
\hline 11 & $\begin{array}{l}\text { Egyptian Authority for } \\
\text { Safety } \\
\text { Navigation } \\
\end{array}$ & $\begin{array}{l}\text { Egyptian Authority for Safety } \\
\text { Navigation }\end{array}$ & http://www.eams.gov.eg/Home/recognition_a \\
\hline \multirow[t]{2}{*}{12} & \multirow{2}{*}{$\begin{array}{l}\text { E-Government Portal } \\
\text { Services }\end{array}$} & \multirow{2}{*}{$\begin{array}{l}\text { Addresses Ministry } \\
\text { and } \\
\text { Government Procurement }\end{array}$} & $\frac{\underline{\text { http://www.egypt.gov.eg/services/LoadxtrServices.asp }}}{\underline{\text { x?PgURL }=73753 \text { \&section }=\text { subjects }}}$ \\
\hline & & & $\frac{\text { http://www.egypt.gov.eg/services/listServicesCategory }}{\underline{\text { aspx? ID }=1285 \& \text { section=subjects }}}$ \\
\hline 13 & Ministry of Tourism & Tourism & $\begin{array}{c}\text { http://www.egypt.gov.eg/services/listServicesCategory } \\
\text {.aspx?ID=1321\&section=subjects }\end{array}$ \\
\hline \multirow[t]{2}{*}{14} & Ministry of Manpower & $\begin{array}{l}\text { The portal of electronic functions } \\
\text { and manpower }\end{array}$ & $\begin{array}{c}\text { http://www.egypt.gov.eg/services/listServicesCategory } \\
\text {.aspx?ID=1326\&section=subjects }\end{array}$ \\
\hline & With disabilities & More services & $\frac{\underline{\text { http://www.egypt.gov.eg/services/LoadxtrServices.asp }}}{\underline{\text { x?PgURL=102853\&section=subjects }}}$ \\
\hline \multirow[t]{2}{*}{15} & $\begin{array}{c}\text { Ministry of Higher } \\
\text { Education and Scientific } \\
\text { Research } \\
\end{array}$ & \multirow[t]{2}{*}{ Education } & http://portal.mohesr.gov.eg/ar-eg/Pages/default.aspx \\
\hline & $\begin{array}{l}\text { Ministry of Education and } \\
\text { Technical Education }\end{array}$ & & $\underline{\text { http://emis.gov.eg/services.aspx } ? \mathrm{id}=1103}$ \\
\hline 16 & $\begin{array}{l}\text { Ministry of Supply and } \\
\text { Internal Trading }\end{array}$ & $\begin{array}{c}\text { Ministry of Supply and Internal } \\
\text { Trading }\end{array}$ & /http://www.msit.gov.eg/ar \\
\hline
\end{tabular}

Table 6:- List of Egyptian E-Government Services 


\begin{tabular}{|c|c|c|c|}
\hline S.N. & Service & Service Name & URL \\
\hline 1 & $\begin{array}{l}\text { Department of Passports, } \\
\text { Immigration and } \\
\text { Nationality }\end{array}$ & $\begin{array}{c}\text { request permission to naturalize foreign } \\
\text { nationality while retaining Egyptian } \\
\text { citizenship }\end{array}$ & $\frac{\text { hhttp://www.egypt.gov.eg/Services/ServiceD }}{\text { etailsFiles.aspx?ID=4763 }}$ \\
\hline 2 & Local units & $\begin{array}{l}\text { Request for a copy of documents in the } \\
\text { local unit }\end{array}$ & $\frac{\text { http://www.egypt.gov.eg/Services/ServiceDe }}{\text { tailsFiles.aspx?ID=4819 }}$ \\
\hline \multirow{2}{*}{3} & \multirow{2}{*}{$\begin{array}{l}\text { Services of Egyptians } \\
\text { Abroad }\end{array}$} & \multirow{2}{*}{$\begin{array}{l}\text { Office of ratifications - Ministry of Foreign } \\
\text { Affairs }\end{array}$} & $\frac{\text { http://www.egypt.gov.eg/Services/ServiceDe }}{\text { tailsFiles.aspx? } \mathrm{ID}=4503}$ \\
\hline & & & $\begin{array}{c}\text { http://www.egypt.gov.eg/Services/ServiceDe } \\
\text { tailsFiles.aspx?ID=4504 }\end{array}$ \\
\hline 4 & Housing services & $\begin{array}{c}\text { Construction and processing - } \\
\text { The phase of use and operation - Utilities - } \\
\text { Ownership and leasing - Property taxes }\end{array}$ & $\begin{array}{c}\text { http://www.egypt.gov.eg/services/servicelist. } \\
\underline{\text { aspx?ID=295\&section=Citizens }}\end{array}$ \\
\hline 5 & Business services & $\begin{array}{l}\text { Work permits - training and employment - } \\
\text { Youth and alumni services }\end{array}$ & $\frac{\underline{\text { http://www.egypt.gov.eg/services/servicelist. }}}{\underline{\text { aspx?ID=312\&section=Citizens }}}$ \\
\hline 6 & Traffic services & Vehicle Licenses / Driving Licenses & $\begin{array}{c}\underline{\text { http://www.egypt.gov.eg/services/servicelist. }} \\
\underline{\text { aspx?ID=321\&section=Citizens }}\end{array}$ \\
\hline 7 & Education services & Schools, Universities and Institutes & $\begin{array}{c}\text { http://www.egypt.gov.eg/services/servicelist. } \\
\text { aspx?ID=327\&section=Citizens }\end{array}$ \\
\hline 8 & Health services & $\begin{array}{c}\text { Health Care - Analyzes of organic materials } \\
\text { - Deaths }\end{array}$ & $\frac{\underline{\text { http://www.egypt.gov.eg/services/servicelist. }}}{\underline{\text { aspx?ID=339\&section=Citizens }}}$ \\
\hline 9 & $\begin{array}{l}\text { Travel and immigration } \\
\text { services }\end{array}$ & Foreign Travel - Immigration & $\frac{\underline{\text { http://www.egypt.gov.eg/services/servicelist. }}}{\underline{\text { aspx?ID=345\&section=Citizens }}}$ \\
\hline 10 & Financial Services & $\begin{array}{l}\text { Insurance \& Pensions - Taxes - Loans - } \\
\text { Compensation - Post Office - Banks }\end{array}$ & $\frac{\underline{\text { http://www.egypt.gov.eg/services/servicelist. }}}{\underline{\text { aspx?ID=353\&section=Citizens }}}$ \\
\hline 11 & Judiciary services & $\begin{array}{l}\text { Documents and certificates - } \\
\text { Representations of inquiries and services }\end{array}$ & $\frac{\underline{\text { http://www.egypt.gov.eg/services/servicelist. }}}{\underline{\text { aspx?ID=365\&section=Citizens }}}$ \\
\hline 12 & $\begin{array}{l}\text { disabilities and the } \\
\text { elderly Services }\end{array}$ & Persons with disabilities / elderly & $\begin{array}{c}\underline{\text { http://www.egypt.gov.eg/services/servicelist. }} \\
\underline{\text { aspx?ID=369\&section=Citizens }}\end{array}$ \\
\hline 13 & Miscellaneous services & $\begin{array}{c}\text { Authority and Directorates of Endowments } \\
\text { - Social Affairs }\end{array}$ & $\frac{\underline{\text { http://www.egypt.gov.eg/services/servicelist. }}}{\underline{\text { aspx?ID=372\&section=Citizens }}}$ \\
\hline 14 & $\begin{array}{l}\text { The Egyptian Book and } \\
\text { Documentation authority } \\
\text { Services }\end{array}$ & $\begin{array}{c}\text { Document Services - Scientific Research - } \\
\text { Libraries - Recitations }\end{array}$ & $\frac{\underline{\text { http://www.egypt.gov.eg/services/servicelist. }}}{\underline{\text { aspx?ID }=1143 \& \text { section=Citizens }}}$ \\
\hline 15 & Pesonal document services & Services of personal documents & $\begin{array}{l}\text { http://www.egypt.gov.eg/services/listService } \\
\text { sCategory.aspx?ID=1232\&section=citizens }\end{array}$ \\
\hline 16 & Tourism services & ELECTRONIC VISA PORTAL & $\begin{array}{c}\text { https://visa2egypt.gov.eg/eVisa/HowDoIApp } \\
\text { ly?VISTK=W00H-4VTK-8DRS-I2IV- } \\
\text { S1LV-ZOIL-OTS2-TSR2-5VW5-GIPP- } \\
\text { GWJU-0UCB-TU1W-D9CF-C7H6-E1EJ }\end{array}$ \\
\hline 17 & Cultural services & $\begin{array}{l}\text { Digital Library of the Bibliotheca } \\
\text { Alexandrina }\end{array}$ & http://dar.bibalex.org/webpages/dar.jsf \\
\hline 18 & Localities and libraries & Localities and libraries & $\begin{array}{l}\text { http://www.egypt.gov.eg/services/listService } \\
\text { sCategory.aspx?ID=1343\&section=citizens }\end{array}$ \\
\hline 19 & Cities & Neighbourhood - cities & $\begin{array}{l}\text { http://www.egypt.gov.eg/services/listService } \\
\underline{\text { sCategory.aspx?ID=1344\&section=citizens }}\end{array}$ \\
\hline
\end{tabular}

Table 7:- List of Egyptian Template and form in E-Government Services 
ISSN No:-2456-2165

\begin{tabular}{|c|c|c|c|c|}
\hline S.N & Domains & Service Provider & URL & Statement of Services \\
\hline \multirow{2}{*}{1} & \multirow{2}{*}{ Health } & $\begin{array}{c}\text { Ministry of Health and } \\
\text { Population } \\
\end{array}$ & http://mhealth.cu.edu.eg & $\begin{array}{l}\text { A distribution system for doctors in } \\
\text { hospitals and medical centres }\end{array}$ \\
\hline & & $\begin{array}{c}\text { Alexandria Dental Research } \\
\text { Center }\end{array}$ & http://www.adrcegypt.com & Alexandria Dental Research Center \\
\hline \multirow{3}{*}{2} & \multirow{3}{*}{ Justice } & \multirow[t]{2}{*}{$\begin{array}{l}\text { Ministry of Justice and } \\
\text { The interests of the real } \\
\text { estate and Documentation }\end{array}$} & $\frac{\frac{\text { http://www.egypt.gov.eg/services/li }}{\text { stServicesCategory.aspx?ID=1301 }}}{\text { \&section=serviceproviders }}$ & $\begin{array}{l}\text { Traffic Prosecution Services - Vehicle } \\
\text { license violations - Traffic } \\
\text { Prosecution Services - Driving license } \\
\text { violations - Traffic Prosecution } \\
\text { Services - Application Tracking } \\
\text { Service - the commissioner's } \\
\text { session roll listing. }\end{array}$ \\
\hline & & & http://rern.gov.eg\#/ & $\begin{array}{c}\text { Contract registration status - } \\
\text { Registration copy extraction - Real } \\
\text { Estate 664ertificate extract }\end{array}$ \\
\hline & & Civil Status Office & https://cso.moi.gov.eg/ & $\begin{array}{l}\text { Divorce Document Extract - Death } \\
\text { Document Extract - Birth } \\
\text { Certificate Extract - Family Record } \\
\text { Extract - Marriage Document } \\
\text { Extract - National ID Extract }\end{array}$ \\
\hline 3 & $\begin{array}{c}\text { Environme } \\
\text { nt }\end{array}$ & Ministry of Environment & $\frac{\text { http://www.eeaa.gov.eg/en- }}{\underline{\text { us/services.aspx }}}$ & $\begin{array}{c}\text { EIA - Fund - Inspection - NGOs - } \\
\text { Training - Public and Investors } \\
\text { Complaints and Inquiries - Licenses - } \\
\text { Coal -Protectorates Services - Ozone } \\
\text { Unit Services - Charcoal. }\end{array}$ \\
\hline \multirow[b]{2}{*}{4} & \multirow[b]{2}{*}{$\begin{array}{l}\text { Public } \\
\text { facilities }\end{array}$} & \multirow[b]{2}{*}{$\begin{array}{l}\text { Electricity Regulatory } \\
\text { Authority } \\
\text { And consumer protection }\end{array}$} & $\frac{\frac{\text { http://www.egypt.gov.eg/services/a }}{\text { vlblservices.aspx?section=servicepr }}}{\underline{\text { oviders }}}$ & $\begin{array}{c}\text { The website of many electricity } \\
\text { companies } \\
\text { and the type of service }\end{array}$ \\
\hline & & & $\frac{\text { http://egyptera.org/ar/a7sb\%20fator }}{\underline{\text { tk.aspx }}}$ & $\begin{array}{c}\text { Calculation of Electricity } \\
\text { Consumption Bill - Electricity Facility } \\
\text { Regulatory Au - Track the power } \\
\text { load - the power facility regulation } \\
\text { authority - Tracking Electricity } \\
\text { Consumption - Electricity Facility } \\
\text { Regulatory Authority - Electricity } \\
\text { Consumption Calculator }\end{array}$ \\
\hline 5 & Investment & $\begin{array}{c}\text { Services of the Ministry of } \\
\text { Environment }\end{array}$ & $\frac{\text { http://www.gafi.gov.eg/english/eSe }}{\underline{\text { rvices/Pages/default.aspx }}}$ & $\begin{array}{l}\text { Companies E-Establishment Service - } \\
\text { General Authority for Investment - } \\
\text { Doing Business in Egypt }\end{array}$ \\
\hline \multirow[b]{2}{*}{6} & \multirow[b]{2}{*}{ Manpower } & $\begin{array}{c}\text { Government jobs portal and } \\
\text { Manpower }\end{array}$ & $\underline{\text { Graduates }}$ & $\begin{array}{c}\text { Follow-up of vacant government posts } \\
\text { - Job Service Evaluation - } \\
\text { Registration of job seekers }\end{array}$ \\
\hline & & Various & $\underline{\text { With disabilities }}$ & $\begin{array}{l}\text { Many of the services provided by : } \\
\text { Ministry of Social Affairs - Ministry } \\
\text { of Health and Population - Ministry of } \\
\text { Education - Ministry of Manpower - } \\
\text { Other Services }\end{array}$ \\
\hline 7 & Education & $\begin{array}{l}\text { Ministry of Education and } \\
\text { Technical Education } \\
\text { And } \\
\text { Ministry of Higher } \\
\text { Education and Scientific } \\
\text { Research }\end{array}$ & $\underline{\text { Students }}$ & $\begin{array}{l}\text { Wishes Registration - Secondary } \\
\text { Coordination Services - } \\
\text { Introduction for the equivalence of } \\
\text { degrees - Inquiry about the request for } \\
\text { equivalence of degrees - Wishes } \\
\text { Results - Wish Registration - } \\
\text { Secondary Azhar coordination } \\
\text { services - Wish Results - Results of }\end{array}$ \\
\hline
\end{tabular}




\begin{tabular}{|c|c|c|c|c|}
\hline S.N & Domains & Service Provider & URL & Statement of Services \\
\hline & & & & $\begin{array}{l}\text { technical certificates - Technical } \\
\text { certificate coordination services - } \\
\text { Wish Registration - Coordinate } \\
\text { Arabic equivalent certificates - } \\
\text { Coordinate Foreign equivalent } \\
\text { certificates - Nile schools for } \\
\text { science and technology - STEM } \\
\text { Schools for science and technology - } \\
\text { Coordination services for Azhar } \\
\text { secondary students applying for } \\
\text { colleges and ins }\end{array}$ \\
\hline 8 & Supply & $\begin{array}{l}\text { Ministry of Supply and } \\
\text { Internal Trading }\end{array}$ & Supply and Internal Trading & $\begin{array}{c}\text { Extracting a new ration card } \\
\text { Extraction of a loss of ration card } \\
\text { Request to open a catering outlet } \\
\text { Request to open a catering bakery }\end{array}$ \\
\hline
\end{tabular}

Table 8:- Classification (E-Services According to Sustainable Development Goals Domains)

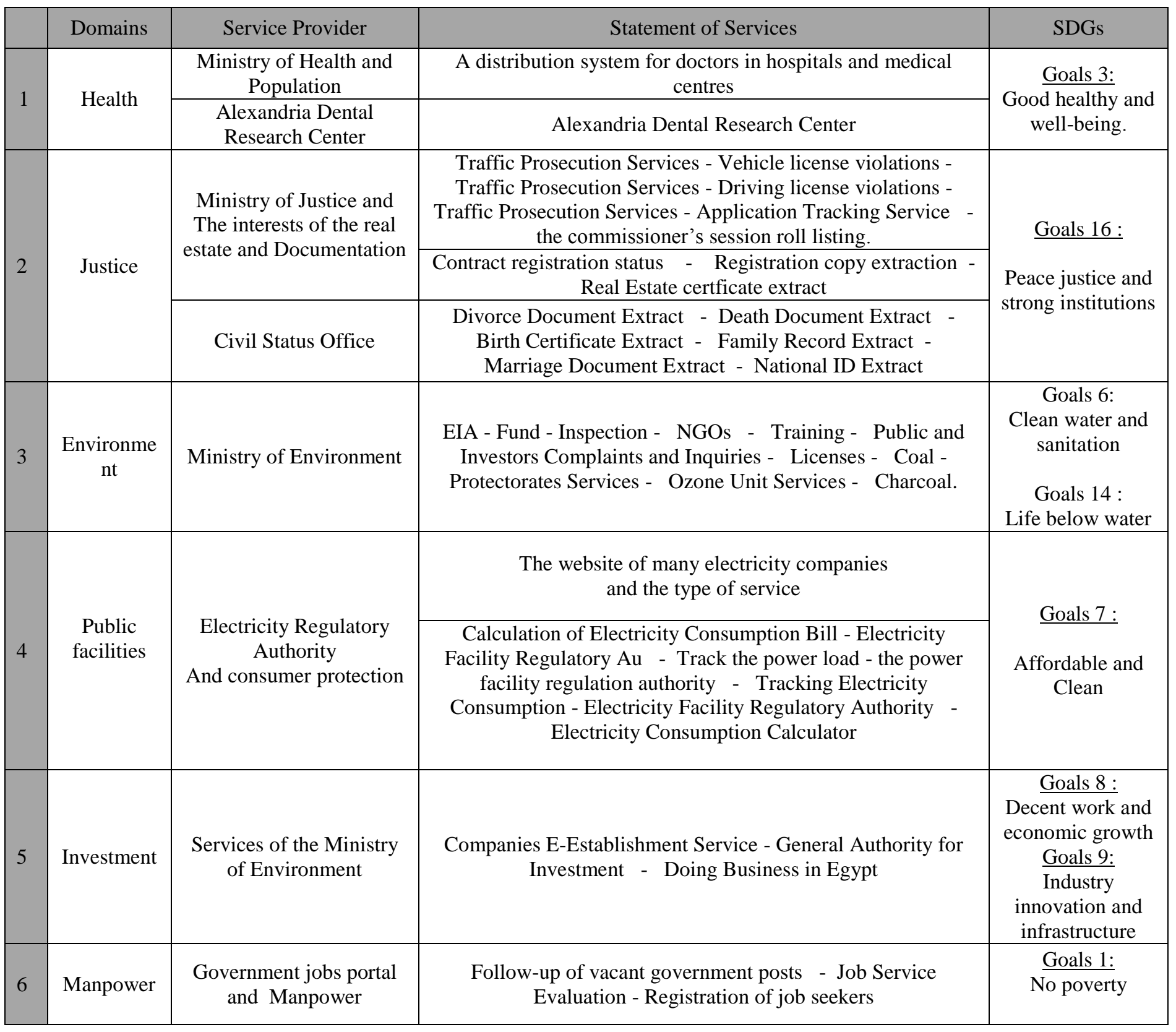


ISSN No:-2456-2165

\begin{tabular}{|c|c|c|c|c|}
\hline & Domains & Service Provider & Statement of Services & SDGs \\
\hline & & Various & $\begin{array}{c}\text { Many of the services provided by : } \\
\text { Ministry of Social Affairs - Ministry of Health and Population } \\
\text { - Ministry of Education - Ministry of Manpower - Other } \\
\text { Services }\end{array}$ & $\begin{array}{c}\text { Goals 8: } \\
\begin{array}{c}\text { Decent work and } \\
\text { economic growth }\end{array} \\
\frac{\text { Goals } 10:}{\text { Reduced }} \\
\text { inequalities. }\end{array}$ \\
\hline 7 & Education & $\begin{array}{l}\text { Ministry of Education } \\
\text { and Technical Education } \\
\text { And } \\
\text { Ministry of Higher } \\
\text { Education and Scientific } \\
\text { Research }\end{array}$ & $\begin{array}{l}\text { Wishes Registration - Secondary Coordination Services - } \\
\text { Introduction for the equivalence of degrees - Inquiry about the } \\
\text { request for equivalence of degrees - Wishes Results - } \\
\text { Wish Registration - Secondary Azhar coordination services - } \\
\text { Wish Results - Results of technical certificates - Technical } \\
\text { certificate coordination services - Wish Registration - } \\
\text { Coordinate Arabic equivalent certificates - Coordinate } \\
\text { Foreign equivalent certificates - Nile schools for science and } \\
\text { technology - STEM Schools for science and technology - } \\
\text { Coordination services for Azhar secondary students applying } \\
\text { for colleges and ins }\end{array}$ & $\begin{array}{c}\text { Goals 4: } \\
\text { Quality education }\end{array}$ \\
\hline 8 & Supply & $\begin{array}{l}\text { Ministry of Supply and } \\
\text { Internal Trading }\end{array}$ & $\begin{array}{l}\text { Extracting a new ration card } \\
\text { Extraction of a loss of ration card } \\
\text { Request to open a catering outlet } \\
\text { Request to open a catering bakery }\end{array}$ & $\begin{array}{l}\text { Goals 1: } \\
\text { No poverty } \\
\text { Goals 2: } \\
\text { Zero hunger }\end{array}$ \\
\hline
\end{tabular}

Table 9:- Mapping (E-Services Services against SDGs)

\begin{tabular}{|c|c|c|}
\hline (SDGs) & Target Number & Domains of Services \\
\hline \multirow{5}{*}{$\begin{array}{l}\text { Goals 1: } \\
\text { No poverty }\end{array}$} & 1.1 & \multirow{2}{*}{ Manpower } \\
\hline & 1.2 & \\
\hline & 1.3 & \multirow{3}{*}{$\begin{array}{l}\text { And } \\
\text { Supply }\end{array}$} \\
\hline & a1 & \\
\hline & b1 & \\
\hline $\begin{array}{l}\text { Goals 2: } \\
\text { Zero hunger }\end{array}$ & 2.1 & Supply \\
\hline \multirow{3}{*}{$\begin{array}{l}\text { Goals 3: } \\
\text { Good healthy and well-being }\end{array}$} & 3.8 & \multirow{3}{*}{ Health } \\
\hline & 3.b & \\
\hline & $3 . \mathrm{d}$ & \\
\hline \multirow[b]{2}{*}{ Goals 4 : } & 4.1 & \multirow{4}{*}{ Education } \\
\hline & 4.3 & \\
\hline \multirow{2}{*}{ Quality education } & 4.4 & \\
\hline & 4.b & \\
\hline \multirow{4}{*}{ Clean water and sanitation } & 6.2 & \multirow{4}{*}{ Environment } \\
\hline & 6.3 & \\
\hline & 6.4 & \\
\hline & 6.b & \\
\hline \multirow[b]{3}{*}{ Affordable and Clean } & 7.1 & \multirow{3}{*}{$\begin{array}{c}\text { Public facilities } \\
\text { And } \\
\text { electricity companies }\end{array}$} \\
\hline & 7.3 & \\
\hline & 7.b & \\
\hline \multirow{2}{*}{ Goals 8 : } & 8.3 & \multirow{3}{*}{$\begin{array}{c}\text { Manpower } \\
\text { And }\end{array}$} \\
\hline & 8.5 & \\
\hline \multirow[t]{2}{*}{ Decent work and economic growth } & 8.6 & \\
\hline & 8.8 & Investment \\
\hline
\end{tabular}


ISSN No:-2456-2165

\begin{tabular}{|c|c|c|}
\hline (SDGs) & Target Number & Domains of Services \\
\hline & 8.10 & \\
\hline & $8 . \mathrm{b}$ & \\
\hline $\begin{array}{c}\text { Goals 9: } \\
\text { Industry innovation and infrastructure }\end{array}$ & 9.3 & Investment \\
\hline $\begin{array}{c}\text { Goals 10: } \\
\text { Reduced inequalities }\end{array}$ & 10.4 & Manpower \\
\hline $\begin{array}{c}\text { Goals } 14 \text { : } \\
\text { Life below water }\end{array}$ & 14.1 & Environment \\
\hline \multirow{3}{*}{ Peace justice and strong institutions } & $\begin{array}{l}16.5 \\
16.9\end{array}$ & \multirow{3}{*}{ Justice } \\
\hline & 16.10 & \\
\hline & $16 . \mathrm{b}$ & \\
\hline
\end{tabular}

Table 10:- The matrix 